\title{
HIGH GRADIENT MEANDER-MODULAR FISH PASSES FOR HYDROELECTRIC POWER OBJECTS
}

\author{
Robert S. Kasperek ${ }^{1 凶}$, Arkadiusz Szkudlarek², Marian Mokwa ${ }^{1}$ \\ ${ }^{1}$ Institute of Environmental Engineering, Wrocław University of Environmental and Life Sciences, pl. Grunwaldzki 24, \\ 50-363 Wrocław \\ 2 INEX, ul. Krawiecka 3/134, 50-148 Wrocław
}

\begin{abstract}
Aim of the paper

The aim of the paper is to determine the hydraulic conditions in the high gradient meander-modular fish pass based on model tests in which the correct migration of aquatic organisms is ensured.
\end{abstract}

\section{Material and methods}

The concept of a new version of the meander fish pass was developed at the Water Laboratory at the University of Environmental and Life Sciences in Wroclaw. A characteristic feature of this fish pass, in addition to its compactness, is the modular structure that can be expanded in any way. The idea of a high gradient meander fish pass is based on a helical surface. The tests were performed on a $1: 3$ scale model based on the Froude similarity criterion. Important elements of the research were measurements of point velocities, stream distribution and turbulence at variable $\mathrm{Q}$ flow.

\section{Results and conclusions}

The tested fish pass model for high gradient meets the basic design assumptions. Velocities in chambers do not exceed the permissible values for fish. At resting places, the velocity does not exceed the limit. The distribution of streams shows that resting places with reduced flow velocities are created inside the chambers. The main difference between meander passes and traditional slot passes is the type of flow in the pools as well as the reduction of energy. The conducted tests show that the water velocities in the interstices of this fish pass are higher than in the slot gaps. The authors recommend designing more pools than for traditional constructions.

Keywords: river, fish migration, hydroelectric power structures, meander-modular fish pass

\section{INTRODUCTION}

As it is well-known, all fish species engage in migrations during the year, related to the implementation of certain stages of their life cycle, e.g. migration to spawn, or to search for more convenient places to prey (Wiśniewolski, 2006). All kinds of dams are obstacles to fish migration, especially upriver.
In order to enable fish to overcome concentrated drops on rivers resulting from artificial water accumulation caused by cross-channel structures, weirs, drops, thresholds or natural accumulation created by waterfalls, constructions called fish passes are built (Mokwa et al., 2007; Mokwa and Wiśniewolski, 2008).

The issue of ensuring ecological continuity of watercourses was being neglected in Poland for many

凶e-mail: robert.kasperek@upwr.edu.pl 
years. Construction of fish passes was often treated as a necessary evil during partitioning of rivers with hydrotechnical structures. Predominantly, fish passes were poorly designed and poorly made. This led to a noticeable decrease in fish population, and some species were permanently removed from Polish rivers (e.g. sturgeon). Over time, however, the scale of the problem was noticed and government programs supporting the construction of fish passes were introduced, e.g. PO RYBY 2006-2012. A number of research works were also carried out and literature on the subject was enriched. Despite this, designing fish passes still causes serious problems for hydrotechnicians, as evidenced by their poor functioning. Many different design solutions for fish passes are known, some more proven, and some less so.

Choosing the type of a fish pass is problematic but most often it's the terrain conditions that are crucial. In urbanized areas, it is not possible to build a semi-natural fish passes with a large number of resting pools, therefore meander-modular fish passes, which take up relatively little space, can play a very important role in designing fish passes. Good technical condition and proper exploitation of damming structures is also an important element for the proper functioning of fish passes (Michalec et al., 2017).

The meander fish pass is a modified version of the slot fish pass. It consists of round chambers and a vertical interstice. It consists of successive chambers located below each other, which creates a sort of a cascade, and the water flowing through is meandering.

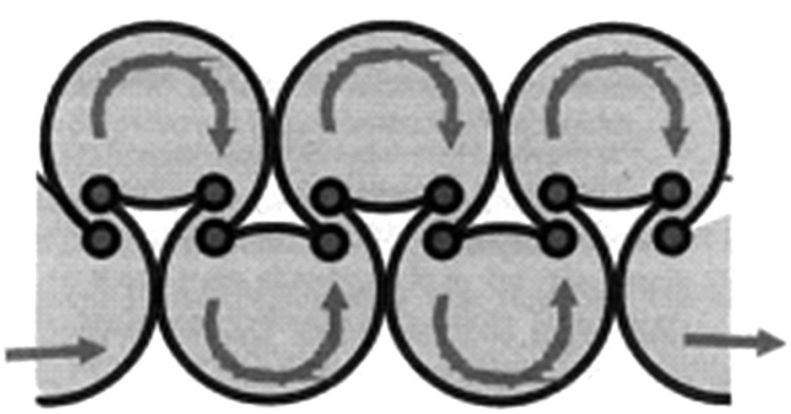

Fig. 1. The arrangement of chambers and the direction of water flow in the meander fish pass (Weise and Thuermer, 1999)
Meander or meandering fish pass is a registered name. The water device was patented in 1999 by the German company "Peters Ökofisch GmbH". The principle of operation of this construction is the dissipation of potential water energy through surface friction against the walls in an elongated flow path. Until now, swirling water by directing it to obstacles was used as a method of energy loss.

Cylindrical chambers usually have a diameter of $1-2 \mathrm{~m}$ and are prefabricated in the form of modules so that they can be mounted directly in the terrain. The difference in levels (the slope) between successive chambers should be about $10-15 \mathrm{~cm}$, while the width of the interstice results from the arrangement of meanders, or it can be adjusted depending on the species of fish and the available flow. The required minimum flow ensuring efficiency is in the range of $0.08-0.30 \mathrm{~m}^{3} \cdot \mathrm{s}^{-1}$ and depends on the size of the chambers (Peters, 2004).

The water flows into interstices of the meander fish pass at a relatively high speed of $1.5 \mathrm{~m} \cdot \mathrm{s}^{-1}$ due to the acceleration it obtains in the chamber that re-

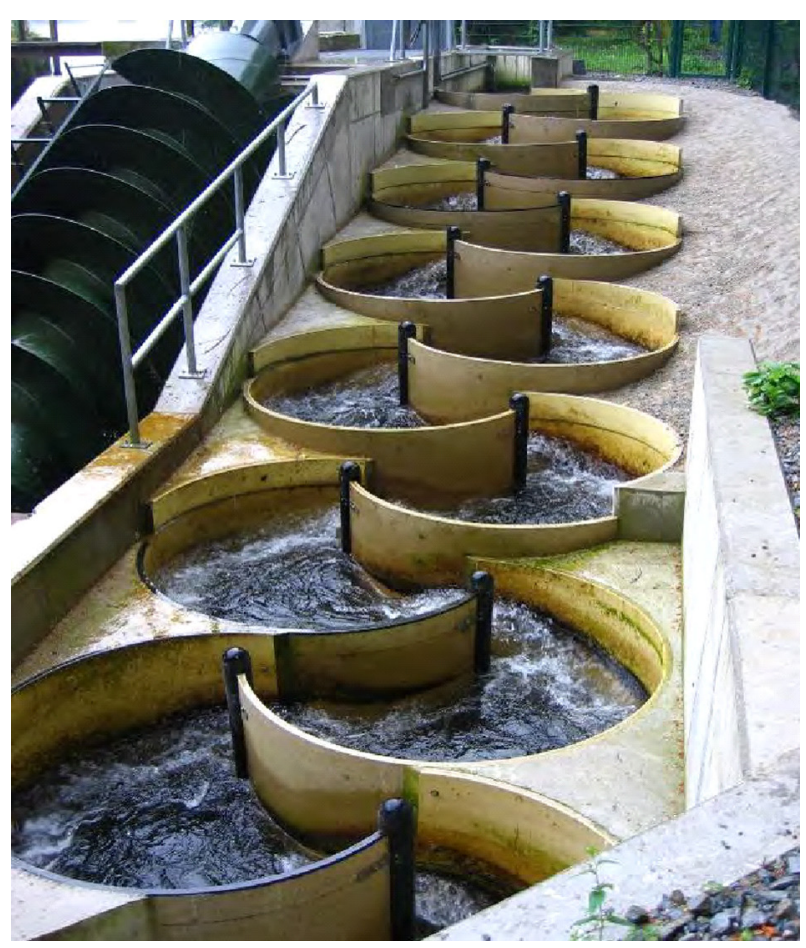

Fig. 2. Example of meander fish pass in North Rhine (Germany) 
sults from the swirling motion. It is advisable that the bottom slope between the chambers is less than $15 \mathrm{~cm}$, and in the case of slot fish passes it can be up to $20 \mathrm{~cm}$.

Under certain hydraulic conditions resulting from calculations with classic formulas, the interstices between the chambers may turn out to be too narrow for some species of fish migrating upriver and should be widened (Peters, 2004). Studies conducted so far have shown surprising usefulness as a device for ascending migration. Specialists from the "DWA" (German Association for Water, Sewage and Waste Management) suggest that their test studies show that chamber diameters should be much larger than in those used by the manufacturer. For salmon, the diameter (or length) of the chamber should not be less than $3.0 \mathrm{~m}$, which corresponds to about three lengths of fish.

The meander fish pass as a device for descending migration does not differ in efficiency from other technical fish passes provided that the inlet to the fish pass is properly shaped (FAO DVWK, 2002). Most of the research on meander fish passes was not independent but ordered by manufacturers, so when building a new meander fish pass it is recommended to check its operation. Opinions among specialists differ significantly regarding the use of these fish passes but the undeniable advantage is the low demand for water and the smaller size of the device (Mokwa and Tymiński, 2017; Mokwa et al., 2012).

The "LfW" laboratory (Labor für Wasserbau $\mathrm{GmbH})$, in cooperation with the "Peters Ökofisch" company, has developed a modification of the meander fish pass - the Helix tower pass - so that it has a wider range of application due to the difference in water levels. Its construction is similar to a winding staircase located inside a round tower. The only device was built in Raisdorf near Cologne, Germany. There is no documented data on its suitability for fish.

It is believed that the undoubted advantages of this type of fish passes are: migration of aquatic organisms, low demand for water, low chance of interstice clogging, no need for frequent cleaning and a smaller size than in case of chamber fish passes. The disadvantages include the artificial nature of the structure and little independent tests confirming its effectiveness.

\section{AIM OF THE PAPER}

The aim of the paper is to determine the hydraulic conditions in the high gradient meander-modular fish pass based on model tests in which the correct migration of aquatic organisms is ensured.

\section{MATERIAL AND METHODS}

\section{Proprietary solutions of meander-modular fish passes}

The concept of a new version of the meander fish pass was developed at the Institute of Environmental Engineering of the University of Environmental and Life Sciences in Wroclaw. A characteristic feature of this fish pass, in addition to its compactness, is the modular structure that can be expanded in any way. The base dimension is the $\mathrm{D}$ diameter of the pipes, which is constant in the meanders of each type of fish pass.

The drawings below show variant solutions (types) of various meander systems. The main difference lies in the arrangement of pipes so that one or two corridors (interstices) for migration are created.

\section{Meander-modular high gradient passes}

The idea of a high gradient meander fish pass is based on a helical surface. The helicoid is a surface formed by a straight rotating around another straight line with a constant angular velocity while moving parallel to this straight line with a constant linear velocity. The name comes from the helicoid's relationship with the helical line (helix). It is also a ruled surface.

\section{Model tests of meander-modular fish passes}

The tests were carried out in the Water Laboratory of the Institute of Water Engineering of the University of Environmental and Life Sciences in Wroclaw, which is equipped with a closed water circuit with the possibility of regulating the flow and water levels. The laboratory also has appropriate instruments for measuring velocity, including a PEMS probe measuring stream distribution and flow rate.

One type of meander-modular single-interstice fish pass was tested in model tests (see: Fig. 10). The construction of the physical model of the meander-mod- 
ular fish pass for high slopes was made in the scale of $1: 3$. The most important element of the structure is a PVC pipe with an internal diameter of $300 \mathrm{~mm}$ from which fish pass chambers are made. Five alternating chambers were modelled. Six interstices were created between the chambers, the edges of which were secured with pipes with a diameter of $28 \mathrm{~mm}$. The slope between the chambers on each interstice was $4 \mathrm{~cm}$.
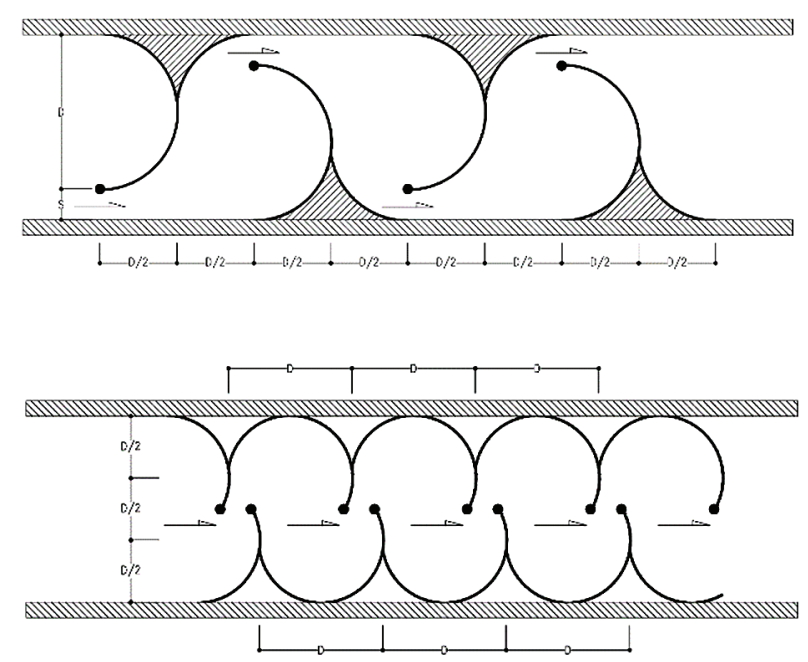

It was assumed that the model was made in the scale of 1:3 in relation to nature. For converting model values into nature, the Froude similarity criterion was used where the individual scale conversion factors are:

- geometric scale: $S_{1}=1: 3$

- velocity scale: $S_{v}=S_{1}^{1 / 2}$

- flow scale $S_{Q}=S_{1}^{5 / 2}$
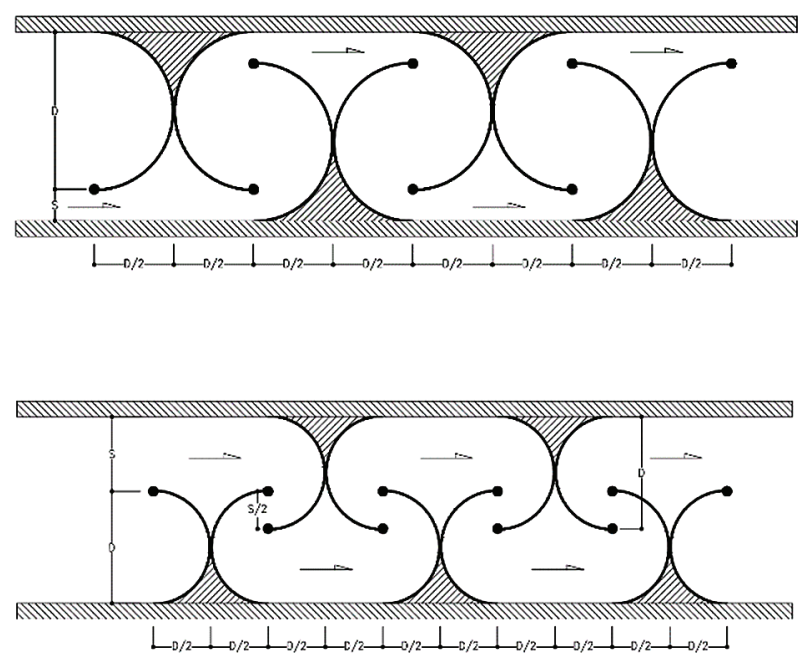

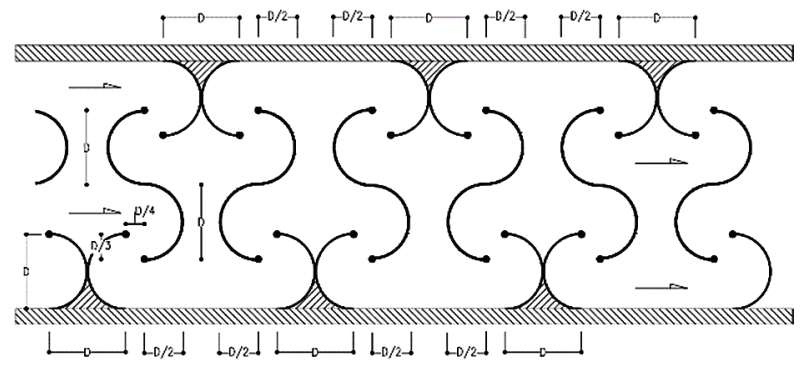

Fig. 3. Examples of proprietary solutions of meanders inside the fish pass 


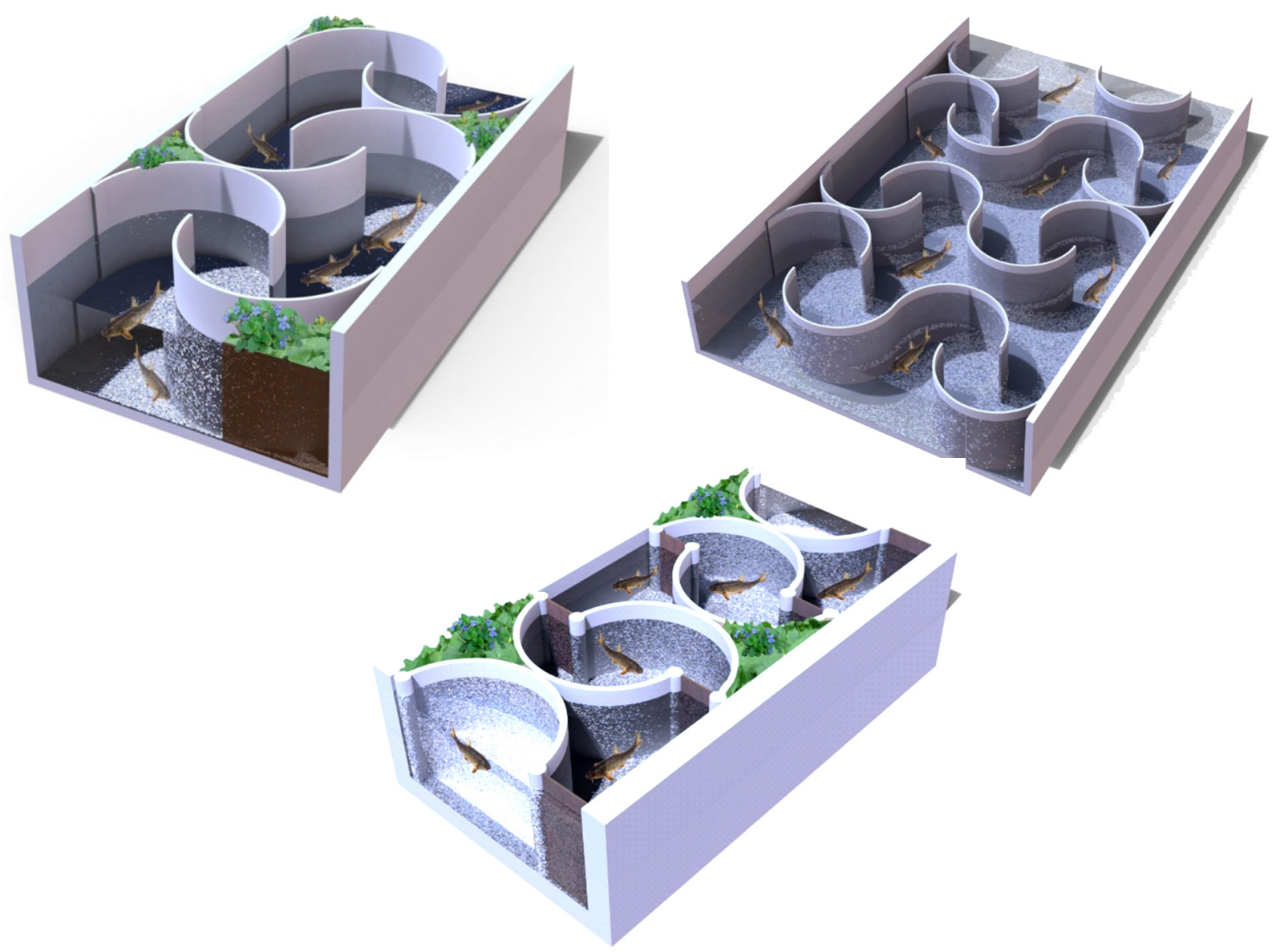

Fig. 4. Examples of proprietary solutions of meanders inside the fish pass

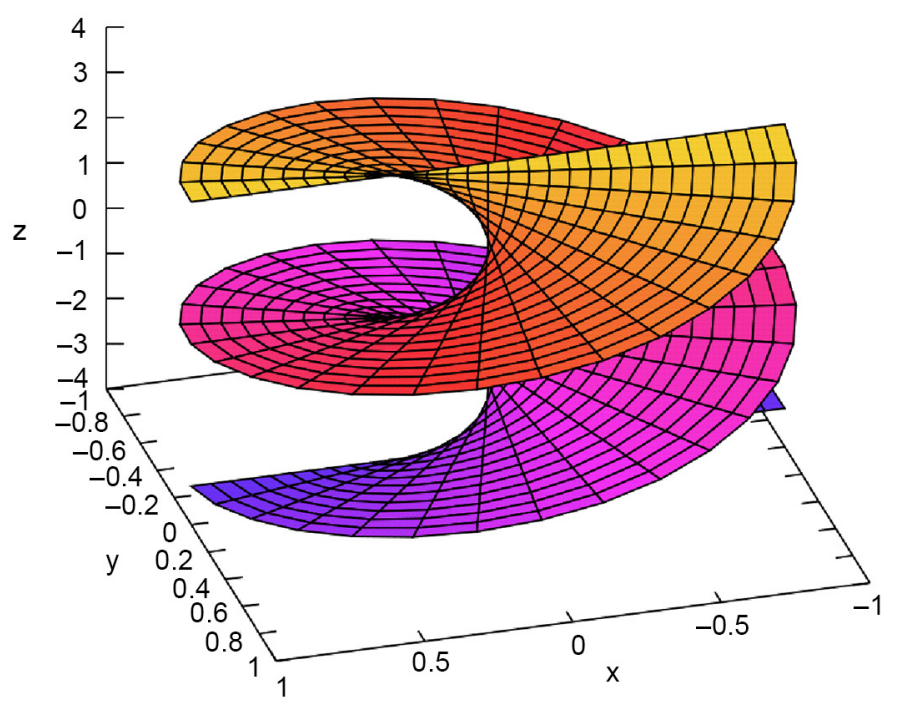

Fig. 5. Diagram of a helicoid in the Cartesian system on a surface with a fish pass designed for high slopes 


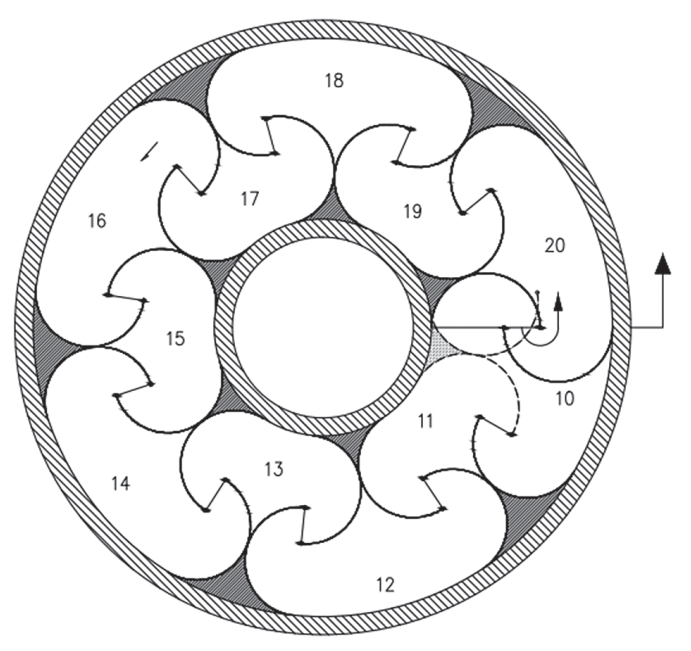

Fig. 6. Diagram of the distribution of chambers in the tested fish pass for high slopes designed on the basis of a helicoid

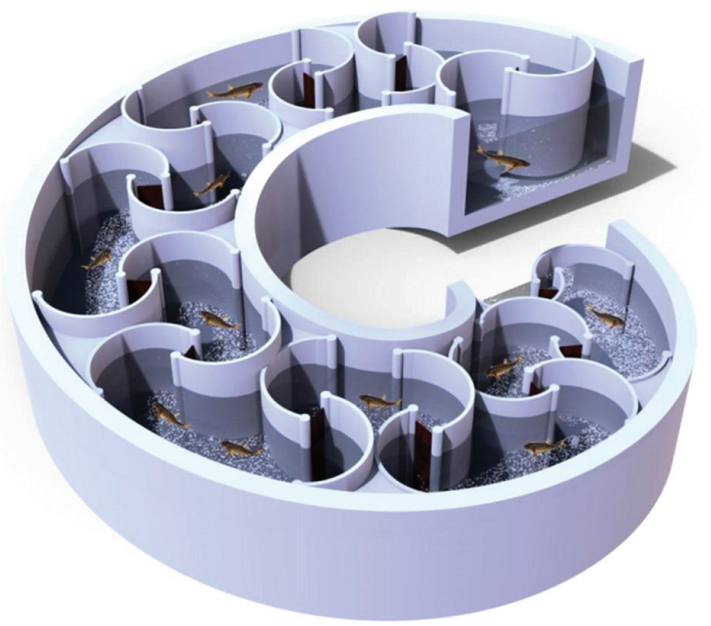

Fig. 7. Diagram of the distribution of chambers in the tested fish pass for high slopes designed on the basis of a helicoid

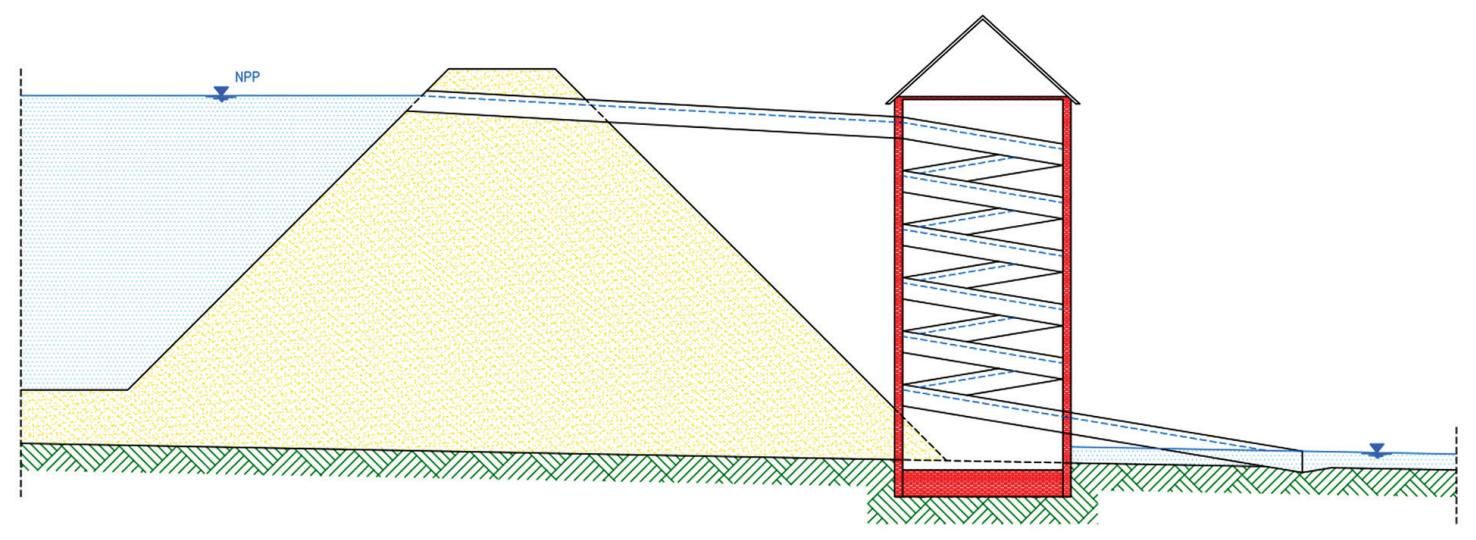

Fig. 8. Diagram of the fish pass location for high slopes by the dam on the downstream face

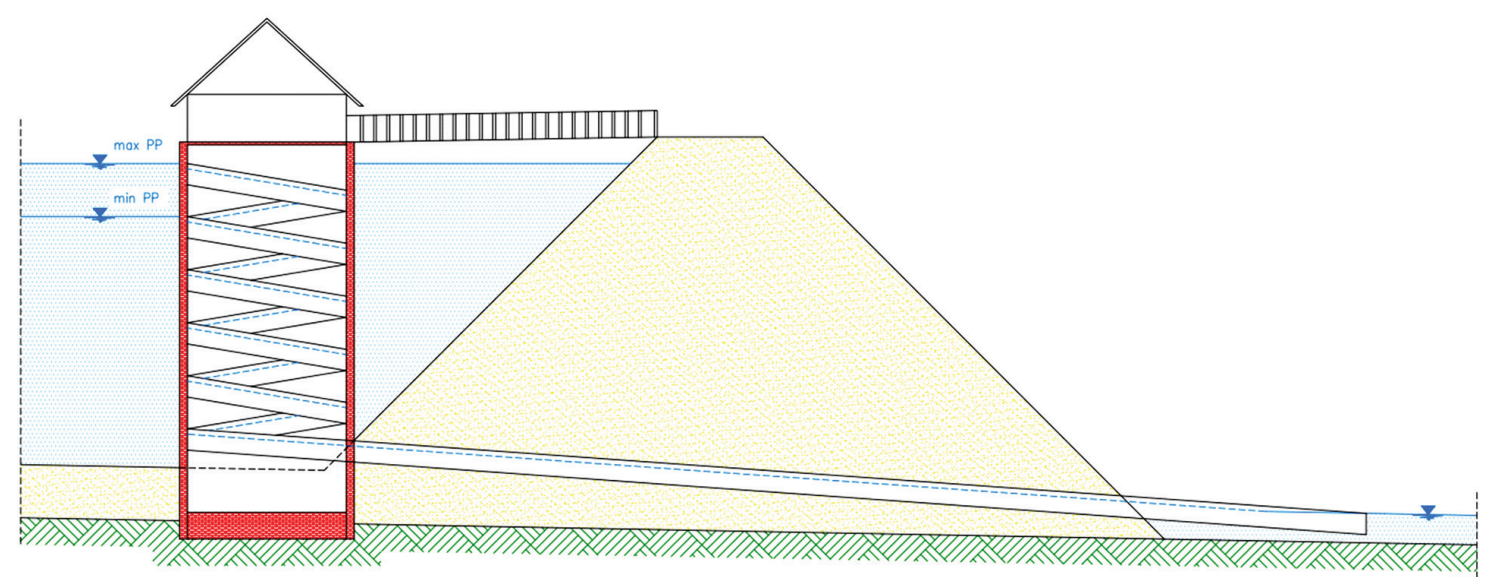

Fig. 9. Diagram of the fish pass location for high slopes by the dam on the upstream face 


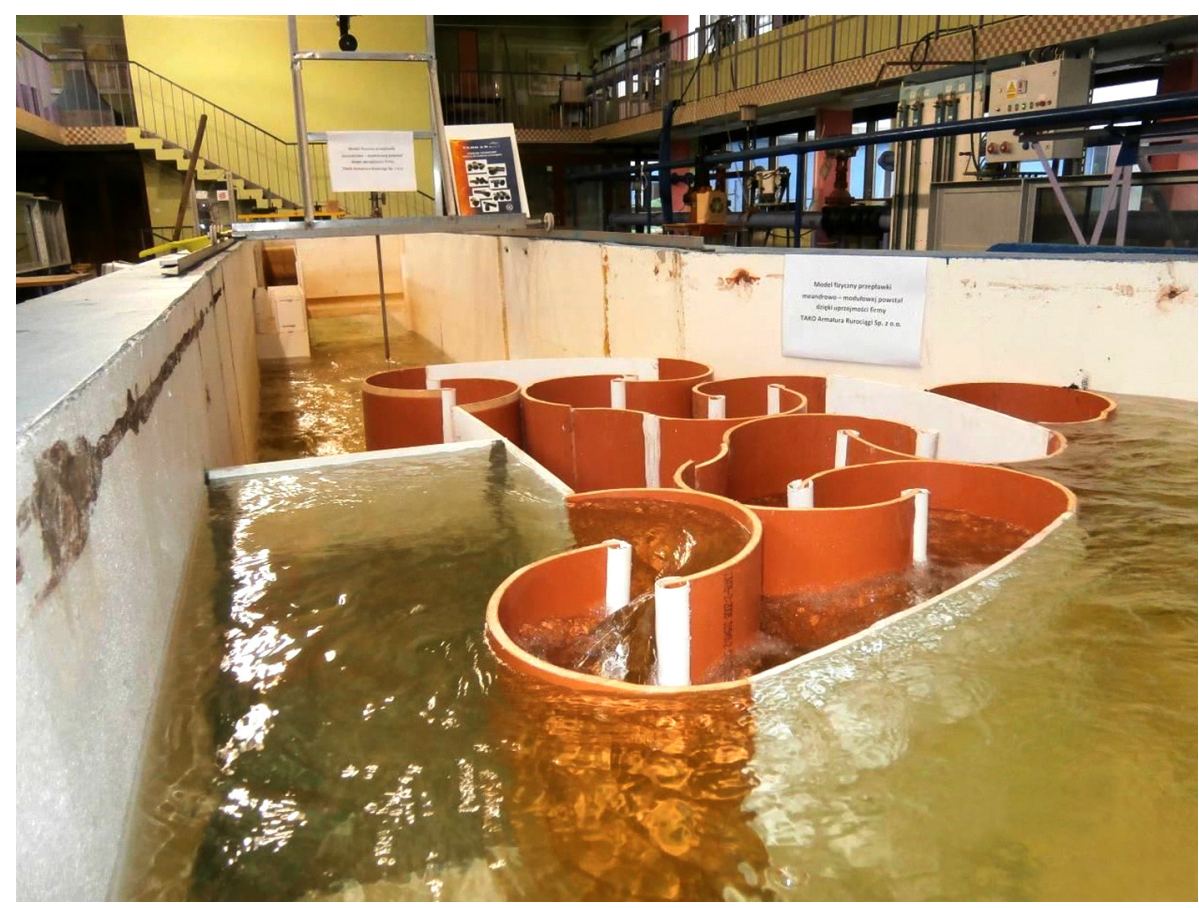

Fig. 10. Location of the tested meander fish pass model for high slopes in the laboratory water bed (Hydraulics Laboratory, Wrocław University of Environmental and Life Sciences)

\section{METHODS AND SCOPE OF RESEARCH}

An important element of the laboratory tests carried out on the meander-modular fish pass were measurements of stream and turbulence distribution in the fish pass at a given flow of $Q$. In this case, two methods of measurement were used. The first method uses a PEMS type electromagnetic probe for multidirectional measurement of instantaneous velocities. Observation of the behaviour of thin threads attached to the probe holder facilitated the correct reading of the stream-specific parameters on the meter screen. The second method is the canon of visualization of hydraulic phenomena in the laboratory. Confetti and a camera on a tripod, with a sufficiently long exposure time, were used in turbulence studies. Unfortunately, in this case turbulence observations are limited only to the surface of the water table. An example of the obtained distribution of surface streams in the tested meander-modular fish pass is shown in Figures 11 and 12.

\section{Hydraulic characteristics of the meander-modular fish pass}

The following recommended calculation formulas for the fish passes (Szkudlarek, 2014) were used

- Flow rate $Q$ :

$$
Q=\frac{2}{3} \mu s \sqrt{2 g h}^{3 / 2}
$$

- Discharge coefficient $\mu$ of the fish pass:

$$
\mu=\frac{Q}{\frac{2}{3} s \sqrt{2 g h}^{3 / 2}}
$$

where:

$Q$ - flow rate, also: $Q=v \cdot F\left[\mathrm{~m}^{3} \cdot \mathrm{s}^{-1}\right], F-$ crosssectional flow area $\left[\mathrm{m}^{2}\right]$,

$v$ - average flow velocity $\left[\mathrm{m} \cdot \mathrm{s}^{-1}\right], \mu$ - discharge coefficient [-],

$s$ - interstice width [m], $g$ - gravitational acceleration $\left[\mathrm{m} \cdot \mathrm{s}^{-2}\right]$,

$h$ - upper water depth $[\mathrm{m}]$. 
Based on the above formula, data obtained from measurements on the model (filling) and the read flow (based on the supply chamber discharge curve), the discharge coefficient was calculated.

Table 1. Calculation of the discharge coefficient for different rates

\begin{tabular}{ccccc}
\hline $\begin{array}{c}\text { Lower water } \\
\text { depth } h_{d}\end{array}$ & $\begin{array}{c}\text { Upper water } \\
\text { depth } h\end{array}$ & $h_{d} / h$ & Flow rate $Q:$ & $\begin{array}{c}\text { Discharge } \\
\text { coefficient } \mu\end{array}$ \\
\hline$[\mathrm{m}]$ & {$[\mathrm{m}]$} & {$[-]$} & {$\left[\mathrm{m}^{3} \cdot \mathrm{s}^{-1}\right]$} & {$[-]$} \\
\hline 0.14 & 0.10 & 1.40 & 0.00516 & 0.550 \\
\hline 0.19 & 0.15 & 1.27 & 0.00891 & 0.517 \\
\hline 0.24 & 0.20 & 1.20 & 0.01216 & 0.458 \\
\hline 0.29 & 0.25 & 1.6 & 0.01534 & 0.414 \\
\hline 0.34 & 0.30 & 1.13 & 0.01856 & 0.381 \\
\hline
\end{tabular}

Fish pass length $L$ :

$$
L=k D
$$

where:

$L$ - fish pass length [m],

$D$ - partition wall diameter (base module) $[\mathrm{m}]$,

$k$ - number of chambers [-]:

$$
k=\frac{H}{\Delta h}-1
$$

$H$ - fish pass fall: difference between upper and lower water level [m],

$\Delta h-$ level difference between adjacent chambers [m]:

Water flow rate $v$ in the fish pass interstice:

$$
\begin{aligned}
& v=\sqrt{2 g \Delta h} \\
& \Delta h=h-h_{d}
\end{aligned}
$$

where:

$$
\begin{gathered}
\Delta h-\text { difference in water levels above and below } \\
\text { the interstice [m] } \\
h \quad-\text { upper water depth; } h_{d}-\text { lower water depth } \\
{[\mathrm{m}]}
\end{gathered}
$$

The measurements of the velocity of flowing water was made at 30 characteristic points inside the fish pass (in the partition wall interstices, at the chamber entrance, in the chamber and at the exit from the chamber). The measurements were made with the PEMS probe at 3 depths: $5 \mathrm{~cm}$ from the bottom, in the middle of the filling and $5 \mathrm{~cm}$ from the water table.

\section{Measurement of water flow directions}

Water flow directions in the fish pass were measured twice. The overall distribution of the streams was determined using threads attached to a stiff wire. Observations confirmed the correctness of the assumptions. Detailed studies of the distribution of the stream on the surface were carried out using paper confetti. The moving confetti were photographed with a digital camera with increased shutter speed (exposure time), and pictures of the surface current system were obtained (see: Fig. 11 and 12).

\section{Ichthyological research}

The distribution of streams and turbulence in fish passes is particularly important from the point of view of the well-being of ichthyofauna (ethohydraulics) and they often determine the effectiveness of these devices (Weise and Thuermer, 1999; Kasperek and Wiatkowski, 2008; Plesiński, 2018). Fish-attracting currents (dominant directions of the streams) must interact with the rest areas for fish, where the water velocity is reduced. Two species of fish were selected for the study: crucian and barbel. Two species of fish were selected for preliminary tests: crucian and barbel, made available by the Stocking center of the Polish Angling Association in Szczodry. Due to the fact that the model was created in the geometric scale of $1: 3$, the fish were also selected relatively smaller. All fish were about $5 \mathrm{~cm}$ long. The aim of the study was to determine whether the hydraulic conditions of stream distribution would create currents encouraging the ascending and descending migration of fish. Velocity conditions were not defined, as lower velocities in the scale of the model allowed migration of all species of fish, regardless of size. The fish were first placed in the upper stand. After a short time, they found the entrance to the fish pass (appropriate attracting current). Both, crucians and barbels, managed to get through the fish pass downstream without problems and damage. After some time, the fish attempted to get through the fish pass upstream. When designing the fish pass in the natural scale, after build- 


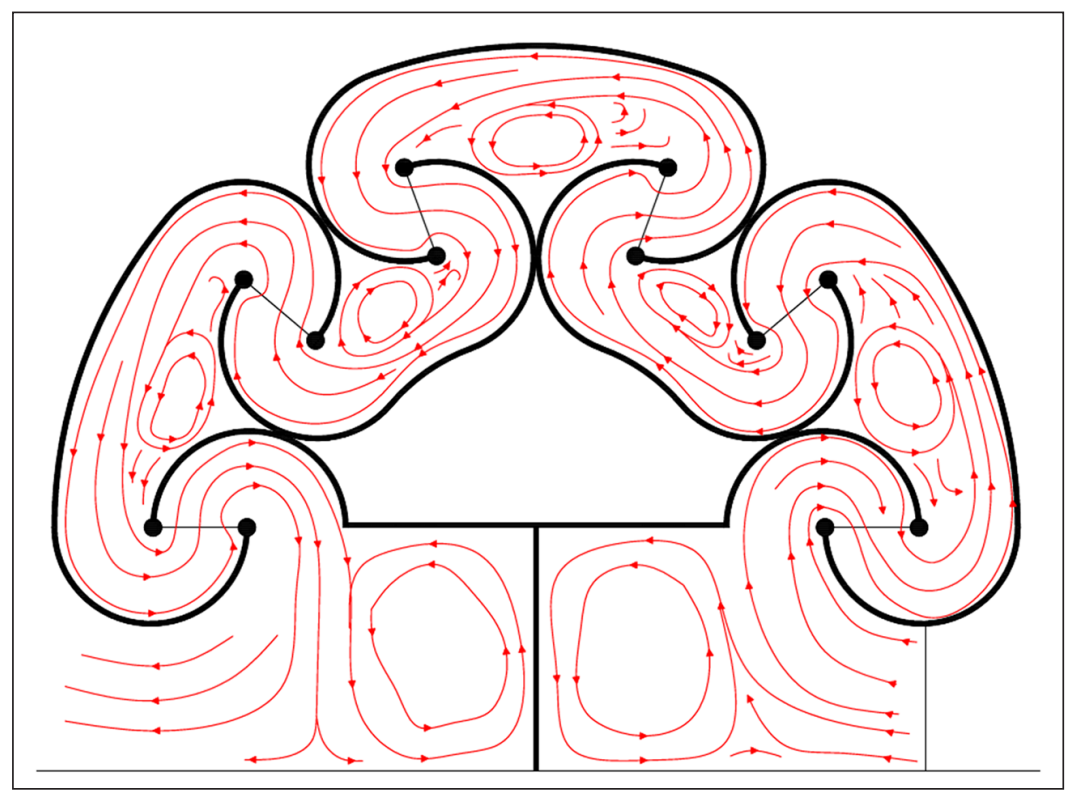

Fig. 11. Interpretation of stream distribution measurements in the model

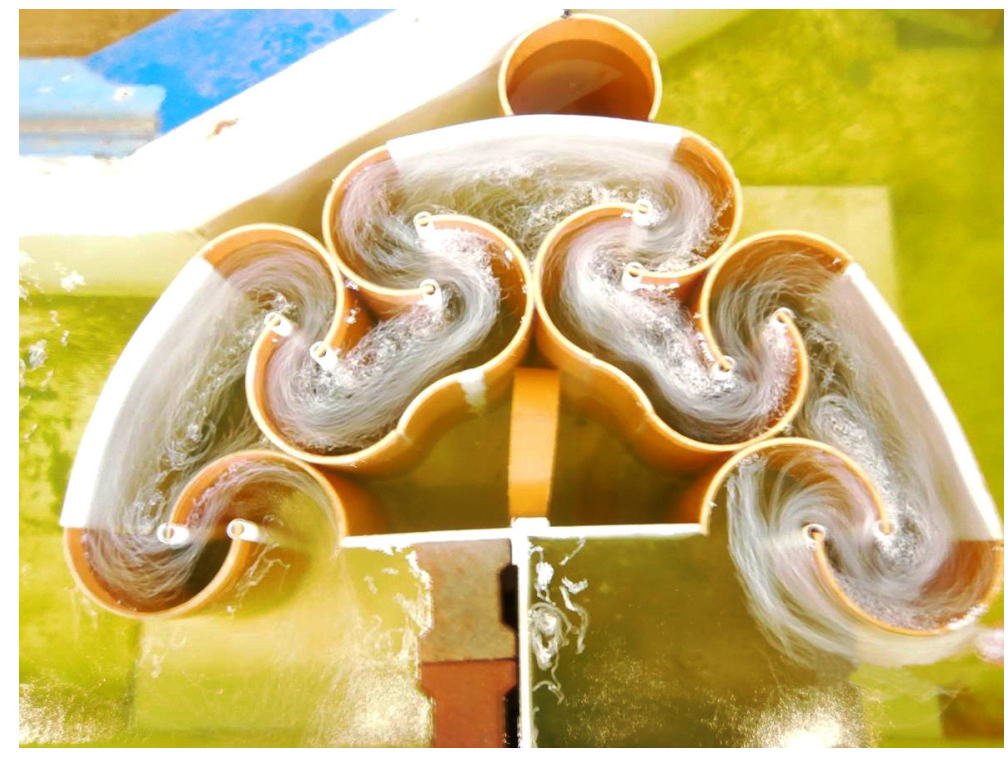

Fig. 12. Visualisation of stream distribution in the model (Hydraulics Laboratory, Wrocław University of Environmental and Life Sciences)

ing it, performance monitoring should be carried out for various fish species. Due to the fact that the model was created in the scale, the fish were also selected relatively smaller. The fish were first placed in the upper stand. After a short time, they found the entrance to the fish pass (appropriate attracting current). Both, crucians and barbels, managed to get through the fish pass downstream without problems and damage. After some time, the fish attempted to get through the fish pass upstream. 


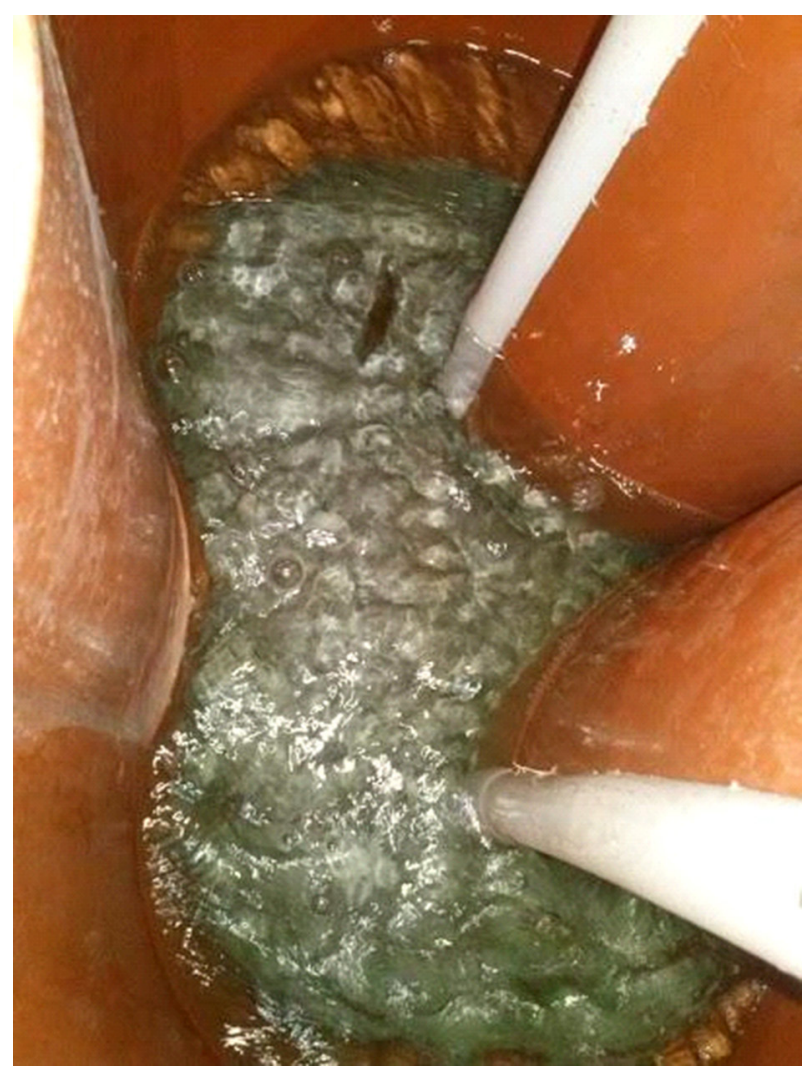

Fig. 13. Young crucian during crossing the fish ladder up the watercourse

\section{DISCUSSION OF THE RESULTS OF MODEL RESEARCH}

The tested meander-modular fish pass model for high slopes proved to be efficient in the laboratory tests. The recommended maximum slope height for which the meander-modular fish passes can be used is approx. $10 \mathrm{~m}$. There is no limit to the slope height due to the hydraulic conditions. Due to the motor features of individual fish species, however, every tenth chamber should be double, without a slope.

The fish pass meets basic design assumptions. The velocities in the fish pass chambers do not exceed the upper limits of the velocity limits for fish (salmonidae $2.0 \mathrm{~m} \cdot \mathrm{s}^{-1}$, rheophilic cyprinidae fish $1.5 \mathrm{~m} \cdot \mathrm{s}^{-1}$, other species $\left.1.0 \mathrm{~m} \cdot \mathrm{s}^{-1}\right)$. However, in resting places the velocity does not exceed the boundary velocity, i.e. about $40-50 \%$ of the maximum velocity value. The research confirmed the design assumptions. The distribution of streams shows that resting places with reduced flow velocities are created inside the chambers.

In the literature (FAO and DVWK, 2002), it is stated that the basic formulas (velocities in interstices, discharge rate) can be used for hydraulic calculations for meander fish passes such as in the case of slot fish passes. Model tests carried out at the Institute of Environmental Engineering have shown that in meander fish passes the results obtained with classic formulas are burdened with a significant error. Therefore, it is recommended to use these formulas with caution. Calculations should be verified with tests on physical or numerical models. The main difference between meander passes and traditional slot passes with rectangular chambers is the type of flow in the pools as well as the reduction of energy. Energy conversion takes place according to the beam theory, essentially by turbulent scattering, whereas the friction on the channel wall is negligible. In the centre of the chamber, the flow velocity is about zero, and the turbulence disappears. Performed tests show that water velocities in interstices are higher than in the case of slot passes with the same lengths of chambers, which results from a larger slope. That is why it is recommended to build much more pools than in the case of conventional constructions with rectangular pools. The discharge coefficient determined in the model tests for different flow conditions is the same as the discharge coefficient for the slot fish pass, given in the publication (FAO and DVWK, 2002) and can be used in design, which was confirmed on two independent types of fish passes (one-slot and two-slot). The volatility characteristics of the discharge coefficient $\mu$ for both types of fish passes have a similar course, while the $\mu$ values for slot fish passes are slightly higher.

\section{CONCLUSIONS AND SUMMARY}

The subject of this study was the conceptual development of several types of meander-modular fish passes for high slopes, which would solve the problems faced by hydrotechnicians in relation to locating them at hydroelectric power buildings on high slopes, and conducting laboratory tests on the selected type of meander fish pass.

Preliminary tests were performed on the model which confirmed that the selected fish pass type 
achieves appropriate hydraulic parameters to ensure safe and free migration of aquatic organisms. Ichthyological tests confirmed the effectiveness of the tested device.

Laboratory tests have shown that the meander-modular fish pass is characterised by hydraulic parameters that enable fish to migrate up and down the river. For the proper functioning of the meander fish pass a relatively small amount of water is required, and the maximum flow depends on its design, i.e. the type and arrangement of the meanders. Compact design is an advantage as, compared to conventional technical passages and "close to nature" circulation fish passes, it does not require too much space for installation. When designing meander fish passes, the size and arrangement of the pools and interstices should be chosen so that fish can easily perform only simple swimming manoeuvres. Therefore, the minimum diameter of a circular pool should equal at least 3 lengths of fish. It is also recommended to increase the interstices by approx. $20 \%$ and to reduce the slopes, e.g. for salmon from $20 \mathrm{~cm}$ to less than $15 \mathrm{~cm}$ between pools, compared to calculations for traditional slot fish passes.

The tested fish pass prototype was successfully tested in a water laboratory. Its complete characteristics can be obtained after building the fish pass in natural conditions and monitoring its effectiveness. The modular-meander fish pass is undoubtedly an interesting alternative to traditional passage solutions for aquatic organisms, as it enables overcoming high slopes more effectively than ever before and it enables ichthyofauna to freely travel along the watercourse. There is a lack of appropriate calculation methods for determining the basic hydraulic parameters, therefore there is still a need to conduct research on this type of object in order to verify its actual efficiency and usability. It is particularly advisable to install continuous monitoring of fish crossing the fish pass.

\section{REFERENCES}

FAO \& DVWK (Food and Agriculture Organization of the United Nations in arrangement with Deutscher Verband für Wasserwirtschaft und Kulturbau e.V.) (2002). Fish passes. Design, dimensions and monitoring.
Kasperek, R., Wiatkowski, M. (2008). Field Studies of Fish Pass Operation on Michalice Reservoir. Rocznik Ochrona Środowiska (Annual Set The Environment Protection), 10, 613-622.

Michalec, B., Cupak, A., Tarnawski, M., Wałega, A. (2017). Assessment of the technical state of the weir at Szczyglice on the Rudawa River. Acta Scientarium Polonorum. Formatio Circumiectus, 16(4), 5-12, DOI: 10.15576/ ASP.FC/2017.16.4.5.

Mokwa, M., Kasperek, R., Wiśniewolski, W. (2007). Laboratory research program of the elekctric-electronic barrier application of ichthyofauna protection. Infrastruktura i Ekologia Terenów Wiejskich (Infrastructure and Ecology of Rural Areas), 4/2, 289-297.

Mokwa, M., Wiśniewolski, W. (2008). Protection of ichthyofauna against the harmful effects of hydrotechnical constructions. Wrocław: Dolnośląskie Wydawnictwo Edukacyjne.

Mokwa, M., Tymiński, T. (2017). Hydraulic Calculations for Fish Passes. In: "Open Channel Hydraulics, River Hydraulic Structures and Fluvial Geomorphology", 98-130.

Mokwa, M., Sobota, J., Tymiński, T., Ciura, M., Goleń, P. (2012). Meandering fish pass of modular design. Gospodarka Wodna, 8, 343-348.

Peters, H. W. (2004). Der Mäanderfischpass. Wasserwirtschaft, 7/8, 16.

Plesiński, K. (2018). Variability of the river bed system and morphology in the region of the block ramp impact (The case of the Porebianka River). Acta Scientarium Polonorum. Formatio Circumiectus, 17(1), 79-93, DOI: 10.15576/ASP.FC/2018.17.1.79.

Radecki-Pawlik, A., Voicu, R., Plesiński, K., Gajda, G., Radecki-Pawlik, B., Voicu, L., Książek, L. (2019). Difficulties with existing fish passes and their renovation. The pool fish pass on Dłubnia River in Krakow, Acta Scientiarum Polonorum. Formatio Circumiectus, 18(2).

Szkudlarek, A. (2014). Hydraulic characteristics of the meander-modular fish pass for high falls (Laboratory tests). Master thesis. Wrocław University of Environmental and Life Sciences.

Weise, A., Thuermer, K. (1999) Errichtung einer Demonstrationsanlage für verschiedene Typen von Fisch-aufstiegsanlagen im Hydrolabor Schleusingen für die Ausbildung von Studenten, Bauhaus-Universität Weimar, (maszynopis).

Wiśniewolski, W. (2006). Ecological continuity of rivers and fish restitution as a condition of eco-development. In: Rybactwo, wędkarstwo, ekorozwój. Monograph (Ed. Arkadiusz Wołos). Olsztyn: Wydawnictwo IRS. 


\section{PRZEPŁAWKI MEANDROWO-MODUŁOWE WYSOKIEGO SPADU PRZY OBIEKTACH HYDROENERGETYCZNYCH}

\section{ABSTRAKT}

\section{Cel pracy}

Celem pracy jest określenie warunków hydraulicznych w przepławce meandrowo-modułowej o wysokim spadzie, w której zapewniona jest prawidłowa migracja organizmów wodnych, na podstawie badań modelowych.

\section{Materiat i metody}

W Laboratorium Wodnym na Uniwersytecie Przyrodniczym we Wrocławiu opracowana została koncepcja nowej wersji przepławki meandrowej dla ryb. Cechą charakterystyczną tej przepławki, oprócz jej kompaktowości, jest struktura modułowa, którą można w dowolny sposób rozbudowywać. Idea przepławki meandrowej wysokiego spadu oparta jest na powierzchni helikoidalnej. Badania wykonano na modelu w skali $1: 3 \mathrm{w}$ oparciu o kryterium podobieństwa Froude’a. Istotnymi elementami badań były pomiary prędkości punktowych, rozkładu strug i turbulencji przy zmiennym przepływie $Q$.

\section{Wyniki i wnioski}

Badany model przepławki dla wysokich spadów spełnia podstawowe założenia projektowe. Prędkości w komorach nie przekraczają dopuszczalnych wielkości dla ryb. W miejscach spoczynku prędkość nie przekracza granicznej. Z rozkładu strug wynika, że wewnątrz komór tworzą się miejsca spoczynkowe o zmniejszonych prędkościach przepływu. Główną różnicą pomiędzy przepławkami meandrującymi a tradycyjnymi przepławkami szczelinowymi jest rodzaj przepływu w basenach, a także redukcja energii. Z przeprowadzonych badań wynika, że prędkości wody w szczelinach tej przepławki są większe niż w przepławkach szczelinowych. Autorzy zalecają projektowanie większej liczby basenów niż w przypadku tradycyjnych konstrukcji.

Słowa kluczowe: rzeka, migracja ryb, budowle hydroenergetyczne, przepławka meandrowo-modułowa 